\title{
Upaya Peningkatan Hasil Belajar Siswa Mata Pelajaran IPA Materi Daur Air dan Peristiwa Alam Melalui Metode Eksperimen dengan Alat Bantu Media Audio Visual di SD Muhammadiyah Boja
}

\section{Rudy Widyanarko}

SD Muhammadiyah Boja

widyanarkorudy@gmail.com

\section{Article History}

received $3 / 12 / 2020$

\begin{abstract}
This classroom action research was used to measure the learning outcomes of science students on water cycle material and natural appearances consisting of pre-cycle, cycle 1, and cycle 2. the interaction of teachers with students is still monotone, so it is proven that the student learning outcomes of 23 students, who completed only 5 students or $21.73 \%$ and the average grade of 57.39. Improvements to cycle 1 were carried out by applying the experimental method with audio-visual media tools, with practicum activities and group discussions, only then there was a change in learning outcomes from 5 students who completed to 11 students who completed with a percentage of $47.82 \%$ and an average score class 64.56 . Then the repair was carried out again with cycle 2, where researchers made improvements by further increasing motivation and guidance to students and further optimizing audio-visual media appropriately, finally student learning outcomes where all students were able to achieve complete scores with a $100 \%$ completeness percentage and an average score. the class reached 79.13. The conclusion is that the application of the experimental method (experimental) with audio-visual media aids succeeded in improving the learning outcomes of class $V$ students in the second semester of SD Muhammadiyah Boja, Boja District, Kendal Regency for the 2019/2020 school year.
\end{abstract}

Keywords: experimental methods, science, and learning outcomes

\begin{abstract}
Abstrak
Penelitian tindakan kelas ini digunakan untuk mengukur hasil belajar siswa IPA materi daur air dan kenampakan alam yang terdiri dari tahapan pra siklus, siklus 1, dan siklus 2 . Hasil Pra Siklus dari 23 siswa, yang tuntas hanya 5 siswa saja atau $21,73 \%$ dan nilai rata-rata kelas 57,39 . Hasil siklus 1 terdapat 5 siswa yang tuntas menjadi 11 siswa yang tuntas dengan presentase $47,82 \%$ dan nilai rata-rata kelas 64,56 . Kemudian diadakan perbaikan kembali dengan siklus 2, dimana peneliti melakukan perbaikan dengan lebih meningkatkan motivasi dan bimbingan kepada siswa serta lebih mengoptimalkan media audio visual dengan tepat, akhirnya hasil belajar siswa dimana keseluruhan siswa mampu meraih nilai tuntas dengan presentase ketuntasan $100 \%$ dan nilai rata-rata kelas mencapai 79,13. Kesimpulannya bahwa penerapan metode eksperimen (percobaan) dengan alat bantu media audio visual berhasil untuk meningkatakan hasil belajar siswa kelas V semester II SD Muhammadiyah Boja Kecamatan Boja Kabupaten Kendal tahun pelajaran 2019/2020.
\end{abstract}

Kata kunci: metode eksperimen, IPA, dan hasil belajar

Social, Humanities, and Education Studies (SHEs): Conference Series https://jurnal.uns.ac.id/shes

p-ISSN 2620-9284 e-ISSN 2620-9292 


\section{PENDAHULUAN}

Kegiatan pembelajaran yang ideal ialah apabila terjadi kegiatan interaksi antara siswa dan guru dengan sumber belajar dalam suatu wilayah lingkungan belajar, dimana guru dan siswa saling bertukar informasi dan saling memiliki keterkaitan antara guru dengan siswa yang memiliki tujuan yang searah. Menurut Komalasari, (2013:13) mendefinisikan pembelajaran sebagai suatu sistem atau proses kegiatna pembelajaran yang direncanakan, dilaksanakan dan dievaluasi secara sistematis supaya guru dapat mencapai tujuan-tujuan pembelajaran secara efektif dan efisien. Untuk mewujudkan kegiatan pembelajaran yang ideal, guru hendaknya mampu untuk mewujudkan kegiatan pembelajaran yang mengarahkan ke dalam tujuan pembelajaran yang sesuai dan tepat.

Piaget (dalam Susanto, 2013: 77) menyatakan bahwa setiap tahapan perkembangan kognitif pada anak mempunyai karakteristik yang berbeda. Secara garis besar dikelompokkan menjadi empat tahap, yaitu: (1) Tahap sensori motor (usia 0-2 tahun) dimana pada tahap ini anak belum memasuki usia sekolah; (2) Tahap praoperasional (usia 2-7 tahun), pada tahap ini kemampuan kognitifnya masih terbatas. Anak masih suka meniru perilaku orang lain (khususnya orang tua dan guru) yang pernah ia lihat dan anak mulai mampu menggunakan kata-kata yang benar dan mampu pula mengekspresikan kalimat-kalimat pendek secara efektif; (3) Tahap operasional konkret (usia 7-11 tahun), pada tahap ini anak sudah mulai memahami aspek-aspek komulatif materi, mempunyai kemampuan memhamai cara mengkombinasikan beberapa golongan benda yang bervariasi tingkatannya selain itu anak sudah mampu berpikir sistematis mengenai benda-benda dan peristiwa-peristiwa yang konkret; 4) Tahap operasional formal (usia 11-15 tahun), pada tahap ini anak sudah menginjak usia remaja, perkembangan kognitif peserta didik pada tahap ini telah memiliki kemampuan mengkoordinasikan dua ragam kemampuan kognitif baik secara simultan (serentak) maupun berurutan.

Berdasarkan pendapat ahli tersebut dapat disimpulkan bahwa karakteristik siswa sekolah dasar yang umumnya berusia antara 7-12 tahun yaitu mulai memiliki rasa ingin tahu yang tinggi dengan cara menyelidiki, mencoba, dan bereksperimen mengenai suatu hal yang dia anggap menarik bagi dirinya serta siswa sudah mampu memhamai cara mengkombinasikan beberapa golongan benda yang bervariasi tingkatannya selain itu anak sudah mampu berpikir sistematis mengenai benda-benda dan peristiwaperistiwa yang konkret. Siswa kelas SD rata-rata berusia 7-12 tahun. Perkembangan siswa SD sesuai dengan perkembangan siswa pada umumnya. Mereka berada pada taraf operasional konkret yang sudah dapat membedakan berbagai jenis benda dan mampu menggolongkan berbagai macam jenis dan peristiwa di sekitar mereka.

Karakteristik siswa kelas V SD Muhammadiyah Boja adalah dari golongan masyarakat yang heterogen, baik dari segi ekonomi, perhatian orang tua maupun status sosial. Tempat tinggal siswa di daerah pinggiran perkotaan kecil. Perkerjaan dari orang tua pun sangat beragam, namun rata-rata mereka bekerja keluar Kabupaten/Kota karena tuntutan gaji yang lebih menjanjikan. Dikarenakan rata-rata orang tua siswa terlampau sibuk dengan pekerjaan merka dan oleh sebab itu siswa merasa kurang perhatian dari orang tua menimbulkan siswa cenderung malas belajar dan kurang memiliki tanggung jawab sebagai siswa untuk belajar. Hal inilah menyebabkan hasil belajar IPA siswa kelas V SD Muhammadiyah Boja masih rendah dan belum mencapai KKM (Kriteria Ketuntasan Minimal).

Bila melihat dari materi dan ruang lingkup yang ada di dalam pelajaran IPA, banyak sekali materi yang menuntut siswa untuk mencari tahu dan membuktikan suatu teori atau melakukan praktikum, dan hal tersebut sangat cocok apabila dilakukan menggunakan metode eksperimen, dimana siswa dapat mencari tahu atau membuktikan suatu teori secara langsung 
Metode eksperimen (percobaan) adalah metode dimana menekankan kepada siswa untuk merasakan secara langsung atau membuktikan sendiri tentang suatu hal, dan menuliskan kesimpulannya, hal ini sangat cocok dan berkaitan dengan pembelajan IPA, dimana didalam materi IPA terdapat banyak sekali praktik secara langsung dalam rangka pembuktian teori dalam materi IPA.

Berdasarkan beberapa uraian dan karakteritik pembelajaran IPA diatas, ternyata kemampuan dan pemahaman siswa kelas V SD Muhammadiyah Boja Kecamatan Boja Kabupaten Kendal tahun 2019/2020 masih rendah, hal ini dikarenakan sistem pembelajaran masih bersifat konvensional dan hal itu terbukti dengan hasil evaluasi, dimana dari 23 siswa, ternyata baru 5 siswa yang mampu mendapat nilai diatas Kriteria Ketuntasan Minimal (KKM) yaitu 70, dimana presentase ketuntasan hanya sebesar $21,73 \%$. Oleh karena itu maka perlu diadakannya perbaikan melalui mekanisme Penelitian Tindakan Kelas dengan menerapkan pembelajaran materi daur air dan peristiwa alam menggunakan metode eksperimen dengan alat bantu media audio visual, supaya hasil belajar dari siswa kelas V SD Muhammadiyah Boja mata pelajaran IPA pada materi daur air dan peristiwa alam tahun 2019/2020 dapat meningkat.

Kemampuan yang dimiliki siswa berbeda-beda setelah ia mendapatkan pengalaman belajarnya. Menurut Bloom (dalam Suprijono 2013:6) hasil belajar terdiri dari kemampuan kognitif, afektif dan psikomotorik. Hasil belajar yang diperoleh siswa dipengaruhi oleh dua faktor yaitu yang berasal dari dalam diri siswa dan faktor dari luar diri siswa. Menurut Caroll (dalam Sudjana 2009:40) terdapat lima faktor yang mempengaruhi hasil belajar siswa antara lain: (1) bakat siswa; (2) waktu yang tersedia bagi siswa; (3) waktu yang diperlukan guru untuk menjelaskan materi; (4) kualitas pengajaran; dan (5) kemampuan siswa.

IImu Pengetahuan Alam (IPA) berkaitan dengan cara mencari tahu mengenai alam. IImu Pengetahuan Alam merupakan terjemahan kata dalam bahasa Inggris yaitu natural science, yang artinya ilmu pengetahuan alam (IPA). Karena berhubungan dengan alam dan science artinya adalah ilmu pengetahuan, jadi ilmu pengetahuan alam (IPA) atau science itu pengertiannya dapat disebut sebagai ilmu pengetahuan alam. IImu yang mempelajari peristiwa-peristiwa yang terjadi di alam ini (Usman Samatowa, 2010: 3).

Roestiyah (2012:80) mengungkapkan yang dimaksud eksperimen adalah salah satu cara mengajar, di mana siswa melakukan suatu percobaan tentang sesuatu hal, mengamati prosesnya serta menuliskan hasil percobaannya, kemudian hasil pengamatannya itu disampaikan ke kelas dan dievaluasi oleh guru. Menurut Roestiyah (2012:80) penggunaan metode eksperimen ini mempunyai tujuan agar siswa mampu mencari dan menemukan sendiri berbagi jawaban atas persoalan-persoalan yang dihadapinya dengan mengadakan percobaan sendiri.

Arsyad (2013: 10) menyampaikan bahwa media pembelajaran adalah segala sesuatu yang dapat digunakan untuk menyampaiakan pesan atau informasi dalam proses belajar mengajar sehingga dapat merangsang perhatian dan minat siswa dalam belajar. Media audio visual adalah media yang mempunyai unsur suara gambar.Jenis media ini mempunyai kemampuan yang lebih baik, karena meliputi kedua jenis media yaitu Media Audio dan Media Visual. Menurut Arsyad ( 2013 : 94 ) media berbasis audio visual adalah media visual yang mengandung penggunaan suara tambahan untuk memproduksinya.

\section{METODE}

Penelitian ini adalah Penelitian Tindakan Kelas adalah suatu kegiatan penelitian ilmiah yang dilakukan secara rasional, sistematis dan empiris reflektif terhadap berbagai tindakan yang dilakukan oleh guru atau dosen (tenaga pendidik), kolaborasi 
(tim peneliti) yang sekaligus sebagai peneliti, sejak mulai disusunnya suatu perencanaan sampai penilaian pada tindakan nyata di dalam kelas yang berupa suatu kegiatan belajar mengajar, untuk memperbaiki dan meningkatkan kondisi pembelajaran yang sudah dilakukan (Iskandar, 2012 : 21). Subjek dalam penelitian perbaikan pembelajaran ini adalah siswa kelas V SD Muhammadiyah Boja Kecamatan Boja Kabupaten Kendal semester 2 tahun 2019/2020 tentang materi daur air dan peristiwa alam.

Pelaksanaan penelitian perbaikan pembelajaran melalui penelitian tindakan kelas dilaksanakan dengan beberapa siklus yaitu pra siklus yang dilaksanakan pada tanggal 13, 14, dan 15 Januari 2020. Siklus I dilaksanakan pada tanggal 3, 4, dan 5 Februari 2020. Siklus II dilaksanakan pada tanggal 10, 11, dan 12 Februari 2020.

Teknik analisis data yang digunakan yaitu terdapat data kualitatif dan kuantitatif. Data kualitatif berupa hasil belajar kognitif yang diperoleh dari soal evaluasi menggunakan teknik analisis deskriptif dengan menentukan rat-rata, median dan modus. Serta menggunakan penyajian data kuantitatif yang dipaparkan dalam bentuk presentase (Anggoro, 2008:6.12). Kemudian untuk teknik penilaian evaluasi pada setiap individu, digunakanlah metode penlaian PAP atau Penilaian Acua Patokan dengan skala 0 - 100. Skala 0 - 100 berangkat dari presentase yang mengartikan skor prestasi sebgai proporsi penguasaan pesrta didik pada suatu tes dengan batas minimal angka 0 (Poerwanti, 2008:6-16). Dalam penelitian ini data kualitatif berupa data hasil observasi aktivitas siswa danketerampilan guru dalam pembelajaran dengan menerapkan media visual, serta hasil catatan lapangan dan angket yang dianalisis dengan analisis deskriptif kualitatif.

\section{HASIL DAN PEMBAHASAN}

- Pelaksanaan perbaikan pembelajaran pra siklus dilaksanakan dengan mekanisme pertemuan pertama, Senin, 13 Januari 2020, pertemuan kedua, Selasa, 14 Januari 2020, dan pertemuan ketiga, Rabu, 15 Januari 2020.

Hasil belajar siswa pada mata pelajaran IPA dengan materi daur air dan peristiwa alam pra-siklus yaitu nilai tertinggi adalah 75, dengan tingkat ketuntasan belajar mencapai $21,73 \%$ atau 5 siswa. Nilai terendah pada pembelajaran pra- siklus adalah 40. Ada 18 siswa yang tidak tuntas atau mencapai 78,27 \%. Nilai rata-rata kelas pembelajaran IPA pra-siklus adalah 57,39 dan KKM kelas $\mathrm{V}$ pada pembelajaran IPA materi Daur Air dan peristiwa alam semester II tahun pelajaran 2019/2020 adalah 70

Tabel 1. Hasil Belajar Siswa Pra Siklus

\begin{tabular}{ll}
\hline Rentang Nilai & Jumlah Siswa \\
\hline $40-49$ & 2 \\
$50-59$ & 12 \\
$60-69$ & 4 \\
$70-79$ & 5 \\
$80-89$ & - \\
$90-100$ & - \\
Tuntas & $5(21,73 \%)$ \\
Belum Tuntas & $18(78,27 \%)$ \\
\hline
\end{tabular}

Dari analisis hasil uji kompetensi menunjukkan bahwa dalam pelaksanaan Pra siklus belum tuntas, terlihat dari 23 siswa ada 18 siswa atau 78,26\% siswa mendapat nilai kurang dari 70,00 dan 5 siswa atau $21,73 \%$ siswa tuntas belajar dengan nilai ratarata kelas 57,39. Dikarenakan hasil evaluasi masih rendah maka diperlukan perbaikan pembelajaran siklus I. Hasil belajar siswa pada mata pelajaran IPA dengan materi daur air dan peristiwa alam siklus I yaitu nilai tertinggi adalah 85 , dengan tingkat ketuntasan 
belajar mencapai $47,82 \%$ atau 11 siswa. Nilai terendah pada pembelajaran siklus I adalah 45. Ada 12 siswa yang tidak tuntas atau mencapai $52,18 \%$. Nilai rata-rata kelas pembelajaran IPA siklus I adalah64,56 dan KKM kelas V pada pembelajaran IPA materi Daur Air dan peristiwa alam semester II tahun pelajaran 2019/2020 adalah 70.

Tabel 2. Hasil Belajar Siswa Siklus I

\begin{tabular}{ll}
\hline Rentang Nilai & Jumlah Siswa \\
\hline $40-49$ & 1 \\
$50-59$ & 4 \\
$60-69$ & 7 \\
$70-79$ & 7 \\
$80-89$ & 4 \\
$90-100$ & - \\
Tuntas & $11(47,82 \%)$ \\
Belum Tuntas & $12(52,18 \%)$ \\
\hline
\end{tabular}

Dalam pelaksanaan perbaikan pembelajaran siklus I siswa kelas $\mathrm{V}$ SD Muhammadiyah Boja Kecamatan Boja Kabupaten Kendal menunjukkan adanya peningkatan dalam penguasaan materi tentang Daur air dan peristiwa alam. Namun baru 11 siswa $(47,82 \%)$ yang tuntas belajar dan masih ada 12 siswa $(52,18 \%)$ yang belum tuntas belajar. Hasil perbaikan pembelajaran siklus I belum memenuhi kriteria ketuntasan yang telah ditentukan, maka perlu disempurnakan pada siklus II.

Dari hasil penelitian perbaikan pembelajaran siklus II telah didapat data sebagai berikut : sebanyak 23 siswa atau 100\% telah berhasil mencapai nilai ketuntasan KKM.

Tabel 3. Hasil Belajar Siswa Siklus II

\begin{tabular}{ll}
\hline Rentang Nilai & Jumlah Siswa \\
\hline $60-69$ & - \\
$70-79$ & 10 \\
$80-89$ & 11 \\
$90-100$ & 2 \\
Tuntas & $23(100 \%)$ \\
Belum Tuntas & $0(0 \%)$ \\
\hline
\end{tabular}

Dalam pelaksanaan perbaikan pembelajaran siklus II, penggunaan metode Eksperimen dan media audio visual pada proses perbaikan pembelajaran IPA materi daur air dan peristiwa alam di kelas V semester 2 SD Muhammadiyah Boja Kecamatan Boja Kabupaten Kendal pelaksanaannya telah berjalan baik dan optimal. Diskusi dan praktikum berjalan efektif, efisien dan sangat menyenangkan serta pengoptimalan media audio visual untuk memaparkan materi sangat jelas dan menarik sehingga pada perbaikan pembelajaran siklus II ini kegiatan menjadi lebih aktif, siswa menjadi antusias dalam bertanya dan mengemukakan pendapat.

Kemudian jika dilihat dari hasil belajar siswa pada uji kompetensi semua siswa mampu mendapat nilai $\geq 70$, dimana nilai rata-rata kelas mencapai 79,13 dengan presentase ketuntasan mencapai $100 \%$. Dari hal tersebut dapat dinyatakan bahwa penerapan metode eksperimen dengan alat bantu media audio visual sangat cocok diterapkan dalam upaya pembelajaran IPA pada materi daur air dan peristiwa alam pada siswa kelas $\mathrm{V}$, karena membuat siswa lebih aktif dan bersemangat serta mengajarkan kepada anak untuk bekerja sama, membuktikan percobaan, serta melatih keberanian, kemandirian dan tanggung jawab pada diri siswa. 


\section{SIMPULAN}

Berdasarkan hasil perbaikan pembelajaran dengan menerapkan metode eksperimen (percobaan) dengan alat bantu media audio visual pada siswa kelas V SD Muhammadiyah Boja Kecamatan Boja Kabupaten Kendal mata pelajaran IPA materi daur air dan peristiwa alam semester 2 tahun 2017/2018 yang dilakukan dalam 2 siklus, dapat ditarik kesimpulan sebagai berikut :

1. Penerapan metode Eksperimen pada mata pelajaran IPA materidaur air dan peristiwa alam dapat meningkatkan hasil belajar siswa kelas $\mathrm{V}$ SD Muhammadiyah Boja Kecamatan Boja Kabupaten Kendal, dimana didapatkan hasil ketuntasan belajar siswa yaitu pada siklus I sebesar 47,82 \% dengan nilai rata-rata kelas 64,56, dan siklus II didapat ketuntasan sebesar $100 \%$ dengan rata -rata nilai 79,13.

2. Penerapan metode Eksperimen dapat meningkatkan keaktifan, kemandirian, kerja sama dan rasa tanggung jawab pada siswa sehingga pembelajaran menjadi menarik dan menyenangkan.

3. Penggunaan media audio visual mampu meningkatkan perhatian dan konsentrasi siswa, serta mempermudah siswa dalam memahami materi.

4. Pemahaman siswa dalam mata pelajaran IPA tentang Daur air dan peristiwa alam dapat ditingkatkan melalui penerapan metode Eksperimen dengan alat bantu media audio visual.

\section{DAFTAR PUSTAKA}

Ahmad, Susanto. (2013). Teori Belajar dan Pembelajaran di Sekolah Dasar. Jakarta: Kencana Prenada Media Group.

Anggoro, dkk. (2008). Metode Penelitian. Jakarta: Universitas Terbuka.

Arsyad, Azhar. 2013. Media Pembelajaran. Depok: PT Raja Grafindo Persada.

BSNP. 2011. Standar Kompetensi. http//bsnp-indonesia.org. Diakases Tanggal 3 Mei 2018 pukul 20.55 WIB.

Djamarah, Syaiful Bahri dan Zain, Azwan. (2007). Strategi Belajar Mengajar. Jakarta: Rineka Cipta.

Hernawan, A.H. dkk. (2007). Belajar dan Pembelajaran SD. Bandung: UPI Press.

Iskandar. (2012). Penelitian Tindakan Kelas. Jakarta: REFERENSI (GP Press Group).

Komalasari, Kokom. (2013). Pembelajaran Kontekstual Konsep dan Aplikasi. Bandung: Refika Aditama.

Mulyasa. (2011). Praktik Penelitian Tindakan Kelas. Bandung : PT. Remaja Rosdakarya.

Poerwanti, E. (2008). Asesmen Pembelajaran SD. Jakarta: Depdiknas.

Roestiyah, N.K. (2012). Strategi Belajar Mengajar. Jakarta: Rineka Cipta.

Sagala, S (2012). Konsep dan Makna Pembelajaran. Bandung: Alfabeta.

Samatowa, Usman. (2010). Pembelajaran IPA di Sekolah Dasar. Jakarta: PT.Indeks.

Sudjana. 2009. Metode Statistika. Bandung: PT.Tarsito.

Suprijono, Agus. (2013). Cooperative Learning Teori dan Aplikasi PAIKEM. Yogyakarta: Pustaka Belajar.

Wardani, I.G.I.K. (2017). Pemantapan Kemampuan Profesional. Cet 9; Ed.2. Tangerang Selatan : Universitas Terbuka.

Wardani, I.G.I.K., Wihardit Kuswaya. (2014). Penelitian Tindakan Kelas. Cet 20; Ed.1.Tangerang Selatan : Universitas Terbuka. 